\title{
Comparing the Incomparable? Performance Measures for National Libraries
}

Poll, Roswitha

First published in:

Alexandria, 20(3), 2008, p. 163-170

Münstersches Informations- und Archivsystem multimedialer Inhalte (MIAMI)

URN: http://nbn-resolving.de/urn:nbn:de:hbz:6-99499421981 


\title{
Comparing the Incomparable? Performance Measures for National Libraries
}

\author{
ROSWITHA POLL
}

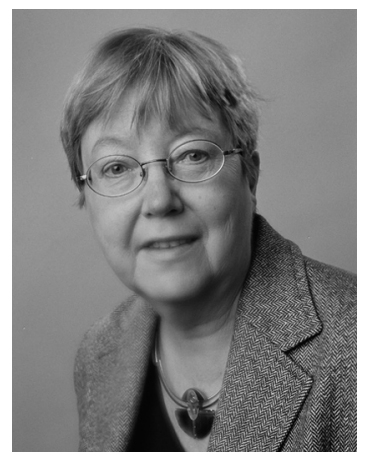

Dr Roswitha Poll was chief librarian of Münster University Library from 1987 to 2004, and is currently working on projects of management and evaluation in information services. She has been chair of the International Organization for Standardization Technical Committee 46 Subcommittee 8 (ISO/TC46/SC8) since 2003 and also chair of the German mirror committee. She has worked in IFLA sections since 1989.

\section{INTRODUCTION}

As a rule, every library will deem itself unique, an institution sui generis, that because of its special tasks, clientele, collections and general conditions cannot meaningfully be compared with other libraries, even of the same type. How much more will this be the case for national libraries, whose range of responsibilities may differ substantially. Can a specified set of performance indicators be used efficiently for different national libraries? Will benchmarking on the basis of such indicators yield reliable results?

The new Technical Report ISO 28118 Information and documentation - performance indicators for national libraries shows definitions and data collection procedures for 30 performance indicators that have been chosen or newly designed for the special tasks and responsibilities of national libraries.

\section{THE HISTORY OF THE PROJECT}

The idea of starting an ISO project especially for national libraries was born in IFLA 2005 in Oslo. Two members of the ISO committee responsible for quality issues in information and documentation (ISO/TC 46/SC 8 Quality - Statistics and performance evaluation) met the Swedish national librarian who addressed the need of quality measures for national libraries. In the midst of the buzzing IFLA coffee shop, the two ISO experts collected a first set of possible measures which during the next months was enlarged and consolidated by mail discussion.

At the next meeting of ISO/TC 46/SC 8 in May 2006 in Paris, the idea met with spontaneous assent. The committee decided that the needs of national libraries were not sufficiently represented in the ISO standard for performance measures (ISO 11620 (2008) Information and documentation - library performance indicators) and that a 'new work item proposal' should be brought forward for this issue; the voting on that proposal was positive. As this would be the first attempt at collecting performance indicators for national libraries, the committee chose the form of a Technical Report, for which there are fewer regulations than for a normal ISO standard. Technical Reports need fewer procedures and less time and can be altered more quickly.

The new working group, with 12 members and 2 guests from 11 countries, met for the first 


\section{PERFORMANCE MEASURES FOR NATIONAL LIBRARIES}

time in January 2007. One of the guests was the chair of the performance measures group within CENL (Foundation Conference of European National Librarians) that had already tried to assess the present use of performance indicators in national libraries (Ambrožic, Jakac-Bizjak and Pecko Mlekuš, 2003). The ISO group also kept in close contact with the National Libraries Section of IFLA, where the indicators were discussed in two meetings.

Bearing in mind the availability of statistics and the collecting procedures in national libraries, several of the libraries represented in the ISO group volunteered to test the indicators that were chosen for the report. The process of drawing up the report was uncommonly quick. Already in January 2008 the working group presented a first full document, and in November 2008 the item was sent to ISO for publication. ISO TR 28118 was finally published on 1 April 2009.

\section{MISSION AND TASKS OF NATIONAL LIBRARIES}

All quality assessment in an institution should proceed from determining what that institution has been set up to do, from the general mission and the main tasks. Therefore, the first task of the ISO group was to define the general mission and the main tasks of national libraries.

The ISO standard for library statistics gives the following definition (ISO 2789, 2006):

National library = library that is responsible for acquiring and conserving copies of all relevant documents in the country in which the library is located; it may function as a legal deposit library.

A national library will also normally perform some orall of thefollowing functions: produce the national bibliography, hold and keep up to date a large and representative collection of foreign literature including documents about the country; act as a national bibliographic information centre; compile union catalogues; supervise the administration of other libraries and/ or promote collaboration; coordinate a research and development service, etc.

In a next step, the group evaluated mission statements on the websites of national libraries, which - in spite of great variety - showed uniformity in the main purposes of national libraries. Additional ideas came from the criteria named by the National Libraries Section of IFLA (http://www.ifla.org/VII/s1/index. htm) and from the participants' experience. All in all, the following general mission was defined:

National libraries have special responsibilities, often defined in law, for a country's cultural heritage. They collect and preserve the national documentary heritage and provide and ensure permanent access to the knowledge and culture of the past and present. They develop central services and take a leading role in the library and information sector.

The Technical Report specifies as main tasks of national libraries:

- to collect and preserve the national imprint ${ }^{1}$ and the national documentary heritage in the form of manuscripts, archival materials, cartographic material, printed music documents, pictures, photographs and audiovisual documents in conventional or electronic format;

- to create the national bibliographic record;

- to maintain a broad collection of foreign publications (often only in specified subjects);

- to provide quick and effective access to the collections, among others by digitizing;

- to promote the national documentary heritage by exhibitions and other cultural events;

1 The national imprint in the sense of the report means all documents in all formats published in a country, including electronic documents and non-commercial publications. 


\section{PERFORMANCE MEASURES FOR NATIONAL LIBRARIES}

- to engage in library and information affairs on a national and international basis;

- to ensure effectiveness and cost-efficiency and provide for staff development.

As possible additional tasks are named:

- to maintain a broad collection of foreign publications;

- to provide a centre for library education;

- to provide central services like the national union catalogue or a national centre for digitization;

- to provide for national library statistics.

National libraries have important tasks that differ from those of other libraries, such as the collection and preservation of the national documentary heritage, the publication of a national bibliography, and a leading role in cooperation. Quality indicators for national libraries must be adapted to these tasks.

\section{PERFORMANCE INDICATORS FOR NATIONAL LIBRARIES}

Performance indicators (also referred to as performance measures or quality indicators) have been in use in libraries for several decades. They measure not only the effectiveness in arranging and delivering services to users but also the cost-effectiveness, the efficient use of existing resources.

Libraries use performance indicators above all for their internal management; the goal is to get detailed knowledge about strong or weak points in the services. If the same indicators are used regularly over years, it will be possible to recognize developments in the service delivery and to follow the effect of measures taken for ameliorating the performance. But the results of performance measurement in an individual library can be difficult to interpret, while they may become meaningful if compared to those of other libraries. Comparison of results will be possible if the libraries have a similar mission and structure, and if all data are defined and collected in the same way.

When the ISO group started its work, it was clear that the hitherto existing performance indicators, devised mainly for academic and public libraries, would not cover the needs of national libraries. Each national library is a unique institution in its country, and therefore data showing the performance of national libraries cannot be compared as easily as those of other library types. As Maurice Line stated, 'no type of library varies so much in nature, size, types of media covered, range of acquisitions, functions and services' (Line, 2001). The responsibilities of national libraries can differ from country to country as they are 'subject to political agendas which change, often more rapidly than for public or academic libraries' (Cullen, 2003).

As far as possible, the ISO group tried to utilize existing indicators. The main issue turned out to be that a great part of these indicators compare the library's input and output to the size of its primary user group or population, for example:

- $\mathrm{m}^{2}$ of user area in the library per member of the population;

- loans per member of the population.

But national libraries have no specified population or primary user group like public libraries, university libraries, school libraries and most special libraries. They are, by their services, serving on the one side the population in their country, on the other side interested persons all over the world. This limited the choice of indicators.

The second edition of the ISO standard 11620 Library performance indicators, published in 2008, describes 45 indicators. Only 15 of these were selected for the Technical Report; they address issues that are relevant for nearly all types of libraries, for example the speed or accuracy of service delivery, cost-effectiveness or staff development. 


\section{PERFORMANCE MEASURES FOR NATIONAL LIBRARIES}

Other performance indicators were found in the handbook Measuring quality (Poll and te Boekhorst, 2007), in the publications of the UK National Preservation Office (Walker, 2006; Walker and Foster, 2006) and in individual evaluation systems of national libraries.

In order to cover all tasks of national libraries, especially the important issues 'national collection' and 'national bibliography', new performance indicators had to be devised and tested. The National Diet Library, Japan, proved especially helpful and efficient in these tests (Tokuhara, 2008).

\section{THE INDICATORS IN THE TECHNICAL REPORT}

Performance indicators for national libraries must be adapted to the special tasks of those libraries. The description of the 30 indicators in the Technical Report is arranged according to the following topics:

- building the national collection;

- making the services accessible by

- cataloguing

- quick and easy access

- usage

- digitization;

- offering reference services;

- building potentials for development;

- preserving the collection;

- managing efficiently.

The description of each indicator follows the structure in the standard ISO 11620:

- name of the indicator;

- aims of the indicator;

- method for collecting and calculating the data;

- interpretation of the results.

But as this is the first time that a systematic collection of quality indicators is offered to national libraries, the ISO group deemed it advisable to give as much help as possible for the use of the indicators. Following the example of the new IFLA handbook (Poll and te Boekhorst, 2007), two clauses were added to each indicator:

- background (describing the service or activity that is evaluated by the indicator and its relevance for national libraries);

- examples and further reading (giving references and examples of a library using the specified indicator or a similar indicator).

The examples can help libraries to realize workload, problems and advantages connected with each indicator and to compare their own results with those of other libraries.

The Technical Report makes a special point of giving examples for libraries using the individual indicator, if possible examples coming from national libraries.

In the following, a selection of indicators is shown for specified tasks of national libraries.

\section{The National Collection and the National Bibliography}

Performance indicators for these crucial tasks of national libraries had to be newly formulated and tested by the ISO group, as standards and handbooks had not considered these issues. Performance indicators for these tasks measure the collection's coverage of the national media production and the speed and comprehensiveness of the national bibliography.

- Percentage of national publications acquired by the national library - This indicator assesses the coverage of the national imprint by the library's collection, including all types of documents.

- Percentage of required national imprint titles in the collection - This indicator assesses whether documents that are required by users and that according to its policy the library should have acquired can be found in the collection. 


\section{PERFORMANCE MEASURES FOR NATIONAL LIBRARIES}

- Percentage of new entries in the national bibliography - This indicator assesses the library's speed of acquisition and cataloguing.

\section{Preserving the National Documentary Heritage}

The national library usually collects not only the national imprint (the national media production), but also the national documentary heritage in the form of manuscripts, archival materials, cartographic material, printed music documents, pictures, photographs and audiovisual documents in conventional or electronic format. Preserving these manifold collections for future generations is seen as a major task of national libraries.

The effort for preserving the national documentary heritage is measured by the following indicators that were taken from methods used in the UK (Walker, 2006; Walker and Foster, 2006) and from the experience of the Bavarian State Library, Munich, Germany:

- Percentage of the collection in stable condition - This indicator assesses to what percentage the collection is suitable for use. Stable material may have some damage but can be used without immediate risk of further damage. Unstable material will be further damaged if used.

- Percentage of all materials needing conservation/restoration treatment that received such treatment - This indicator shows the library's engagement in restoration activities per year.

- Percentage of the collection housed in the appropriate environment - This indicator assesses whether the collection is stored in an environment with adequate temperature, humidity, lighting and air quality.

Digitizing the National Documentary Heritage National libraries offer their collections for usage. But as they possess a great part of rare or even unique items, care must be taken to combine access to the collections with conservation of the materials. Since the Internet allows access to digital library collections for remote users worldwide, digitization of collections has proved an efficient way to solve this problem. When national libraries engage in digitization projects, they have two different purposes: to make their cultural heritage collections universally available via digitization projects, and to conserve the original analogue material by substituting a digital surrogate.

The performance indicators for digitization consider first the whole collection, then the special collections, and lastly the usage of digitized items:

- number of documents digitized per 1,000 titles in the collection;

- percentage of documents digitized per special collection;

- number of content units downloaded per document digitized.

\section{The Cultural Role of National Libraries}

National libraries are important cultural venues in their country and beyond. Therefore indicators had to be identified that illustrate this role.

National libraries collect and preserve collections that have a singular value. Therefore they try to raise the awareness of their collections, especially of the rare collections, by exhibitions and other events. Such events must not be restricted to the collections and can have a cultural, literary, educational or scholarly intent, for example exhibitions, author visits, literary discussions, workshops, and so on.

In addition, national libraries often take a leading part in library research and development, both nationally and internationally. Their investment of staff resources in library cooperation and library-related projects can therefore be regarded as an indicator of the library's engagement in its national and international role.

The indicators selected for this issue are:

- Number of attendances for cultural events - 


\section{PERFORMANCE MEASURES FOR NATIONAL LIBRARIES}

This indicator shows the attractiveness of library-organized events.

- Percentage of staff in national and international cooperation and projects - This indicator shows the library's engagement in cooperation and its importance in and impact on the library world.

\section{General Indicators of Library Quality}

There are quality aspects that apply to all types of libraries. Such aspects are the speed, accuracy and reliability of the services, the cost-efficiency of the service delivery, and the library's potentials for development.

Indicators for these quality issues were selected from the standard ISO 11620. Examples for such indicators are:

- median time of document retrieval from closed stacks;

- speed of reference transactions;

- cost per download per electronic resource;

- employee productivity in media processing;

- number of attendance hours at formal training lessons per staff member.

The indicators were not copied from ISO 11620 without change, but were adapted to the special needs and conditions of national libraries. An example of this is the performance indicator 'User satisfaction'.

User satisfaction can be assessed with various methods, reaching from the simple evaluation of complaints and suggestions to elaborate systems like LibQUAL $+{ }^{\mathrm{TM}}$ (http://www.libqual.org). The ISO group chose a user satisfaction survey that asks for the users' satisfaction with the library's services and products. Such surveys are well known in libraries, but the problem for national libraries was: what is the clientele that the libraries ought to survey?

In libraries with a defined population to be served, for example university libraries, public libraries, or special libraries serving the members of an institution or commercial firm, it will be comparatively easy to assess user satisfaction, as the libraries know the size, structure and level of education of their population. National libraries have no such specified clientele; their services can be used by interested persons worldwide. User surveys of national libraries therefore will have to consider different user groups:

- walk-in users, using for example the library's reading rooms;

- remote users (worldwide);

- publishers;

- other libraries that use the national library's services.

Each survey must be adapted to the needs of the specified user group. The Technical Report gives advice on how to design such surveys.

\section{A Recent Task of National Libraries: Web Archiving}

A number of national libraries have started, each in a different way, to select, collect and store publications and websites out of their national domain, understanding this as a task similar to the traditional legal deposit. Problems are manifold for the wide field of Internet resources:

- the scope and boundaries of the collections;

- copyright issues;

- methods of collecting;

- frequency of collecting;

- storage formats and indexing;

- access to the collections for the public.

The Technical Report is the first ISO publication to handle this topic. As the selection policies and the methods of collecting and storing the Internet resources are as yet still developing, the ISO group considered it best to treat the topic in a short Annex. This Annex gives a first overview of current methods and definitions and shows possible quality criteria for the collection of Internet resources, but does not yet describe performance indicators for this new task. 


\section{PERFORMANCE MEASURES FOR NATIONAL LIBRARIES}

As the topic will be of growing importance, ISO TC 46 SC 8 in its yearly meeting in March 2009 proposed a new work item: a Technical Report aimed at web archiving. If a sufficient number of SC 8 member states register for this proposal, work on the topic could start at the end of 2009.

\section{THE PURPOSE OF THE TECHNICAL REPORT}

The new Technical Report ISO 28118 offers a broad selection of performance indicators for national libraries. But there is another group that can benefit from the Report: regional libraries. Like national libraries, regional libraries have no defined clientele, but serve a wider public. They collect the media published in a specified region and media dealing with that region.

The 30 indicators in the Report are not meant to be compulsory, but as a collection to choose from, according to the tasks and goals of the individual library. However, the use of performance indicators in the individual library cannot be as effective as when a group of libraries join in that process. An individual library evaluating the quality of its services by using the same performance indicators repeatedly will be able to recognize problems and developments over years. But in many cases it will be difficult to assess whether their own results are indeed good or bad. If for example the indicator 'shelving accuracy' shows that only $94 \%$ of books in the collection are in their right place, the library will know by itself that this might be much better, especially in closed stacks. But is it 'good' if a staff member in the media processing department handles 2,000 media per year, or if it takes 50 minutes on average to fetch books from closed stacks? In such cases, the comparison with other libraries with similar missions and structures can show whether results are poor, excellent or just middling. Benchmarking will give meaning to an individual library's data. This applies even to national libraries, as the examples in the Report show.
Indicators for outcome and impact are not yet included in this Report, though it would of course be most interesting to show the national libraries' contribution to knowledge, information literacy, social inclusion, academic and professional success, or cultural life. Options of assessing libraries' impact on the individual user as well as on society have been tested in a number of projects in recent years, and some promising methods have been identified. This topic will probably be taken up by ISO committees in the next years.

\section{REFERENCES}

Ambrožic, M., Jakac-Bizjak, V. and Pecko Mlekuš, H. (2003) 'Performance evaluation in European national libraries: state-of-the-art', World Library and Information Congress, 69th IFLA General Conference and Council, Berlin, http://www.ifla.org/IV/ifla69/papers/ 024e-Ambrozic_Jakac-Bizjak_Mlekus.pdf (visited 4.4.09).

Cullen, R. (2003) 'Benchmarking: overview and context', World Library and Information Congress, 69th IFLA General Conference and Council, Berlin, http://www.ifla.org/ IV/ifla69/papers/015e-Cullen.pdf (visited 4.4.09).

ISO 2789 (2006) Information and documentation - international library statistics. Geneva: ISO, 2006.

Line, M. (2001) 'Changing perspectives on national libraries: a personal view'. Alexandria, 13(1), 2001, p. 44.

Poll, R. and te Boekhorst, P. (2007) Measuring quality, performance measurement in libraries. 2nd revised ed. Munich: Saur, 2007. IFLA Publications 127.

Tokuhara, N. (2008) 'ISO/TR28118: Establishment of performance indicators for National Libraries'. Current Awareness, 295, 20 March 2008, http://current.ndl.go.jp/ ca1653 (Japanese text only).

Walker, A. (2006) Basic preservation guidelines for library and archive collections. London: 
PERFORMANCE MEASURES FOR NATIONAL LIBRARIES

National Preservation Office, 2006, http:// www.bl.uk/npo/pdf/basic.pdf (visited 4.4.09).

Walker, A. and Foster, J. (2006) Knowing the need, a report on the emerging picture of preservation need in libraries and archives in the UK. M. Feeney (ed.). London: National Preservation Office, 2006, http://www.bl.uk/ npo/pdf/knowing.pdf (visited 4.4.09).

\begin{abstract}
The article describes the process of developing performance measures for national libraries, which culminated in the publication in April 2009 of the International Organization for Standardization Technical Report ISO 28118 Information and documentation - performance indicators for national libraries. An ISO working group began by defining the general mission and main tasks of national libraries. Most existing performance indicators, devised mainly for academic and public libraries, compared a library's input and output to the size of its primary user group. However, national libraries do not have such a defined user group - a fact that had to be reflected in the chosen indicators, which cover: building the national collection; making services accessible; offering reference services; building potentials for development; preserving the collection; and managing efficiently.
\end{abstract}

